\title{
THE INCIDENCE OF PSEUDOPREGNANCY AFTER ERGOCORNINE-INDUCED INTERRUPTION OF THE LUTEAL PHASE IN THE RAT
}

\author{
E. S, KISCH* \\ Department of Biodynamics, Weizmann Institute of Science, Rehovoth, Israel
}

(Received 14th May 1968)

The induction of pseudopregnancy in the rat abolishes, for about 8 days, the hypothalamic inhibition of pituitary luteotrophic hormone (LtH) secretion (Zeilmaker, 1965). Pituitary $\mathrm{LtH}$ is available throughout this period, whether functional corpora lutea are present or not. If a new oestrus is induced during this 8-day period, this oestrus is followed by a fresh pseudopregnancy of normal length, still benefiting, as it were, from the prior stimulus which initiated $\mathbf{L} t \mathrm{H}$ secretion and induced the first pseudopregnancy; the stimulus is 'remembered' in the central nervous system (Everett, 1967).

Ergocornine interrupts progestation in the pregnant and pseudopregnant rat, and oestrus appears within 2 to 3 days of administration of the ergot alkaloid (Shelesnyak, 1955). This oestrus, caused by the interruption of gestation, is followed in 50 to $70 \%$ of cases by prolonged periods characterized by leucocytic vaginal smears (Kraicer \& Shelesnyak, 1964; Zeilmaker, 1965). The prolonged di-oestrous phases were identified as pseudopregnancies because deciduomata could readily be stimulated during these periods. In most of the experiments reported (Kraicer \& Shelesnyak, 1964; Zeilmaker, 1965), ergocornine was administered to rats on Day $\mathrm{L}_{4}$ of pregnancy or pseudopregnancy (the day spermatozoa are found in the vagina is designated as Day $\mathrm{L}_{0}$, and the subsequent days of leucocytic smear as days $L_{1}$ to $L_{n}$ ). The induced oestrus occurred 2 to 3 days later and thus fell within the limits of the 8-day period of enhanced pituitary luteotrophic activity (cf. Zeilmaker, 1965).

We examined Zeilmaker's thesis of an 8-day state of uninhibited luteotrophin secretion, and Everett's 'memory' concept, by testing the relation of time of ergocornine administration to incidence of a following 'secondary' pseudopregnancy.

The initial pseudopregnancy was induced by electrical stimulation of the cervix uteri on the day of oestrus in rats from the Biodynamics colony. Animals (twenty/group) received ergocornine methanesulphonate $(1 \mathrm{mg}$ in $0.25 \mathrm{ml}$ of $70 \%$ alcohol subcutaneously) on Day $\mathrm{L}_{2}$ or Day $\mathrm{L}_{4}$ or Day $\mathrm{L}_{7}$ of pseudopregnancy, i.e. early, midway or late during the period of luteotrophic activity induced by cervical stimulation. Oestrus occurred within 2 to 3 days after ergocornine injection, that is on the 4th to 6 th, 6 th to 7 th or 9 th to 10 th day, respectively, after induction of the primary pseudopregnancy. According to Zeilmaker's concept, the group wherein oestrus appears on the 9th to 10th

\footnotetext{
* Lalor Foundation Fellow (1966-67).
} 
day should show few or no secondary pseudopregnancies; where oestrus is induced early $\left(\mathrm{L}_{4}\right.$ to $\left.\mathrm{L}_{6}\right)$ pseudopregnancy should appear in most or all rats.

Vaginal smears were examined daily. The incidence of 'secondary' pseudopregnancies, shorter than normal in all groups, is detailed in Table 1.

Our results are consistent with the contention that induction of pseudopregnancy is 'remembered' for some time in the rat and that the induced luteotrophic potential may become manifest at a later period, after a new oestrus, depending on the interval between the original pseudopregnancyinducing stimulus and the following oestrus. Apparently, the 'memory' fails gradually, and we did not find a circumscribed 8-day period of activity. The induction of 'secondary' pseudopregnancies is dependent on the time at which the original pseudopregnancy is interrupted and oestrus is induced, whatever the method used (cf. Zeilmaker, 1965); the response is not specific to ergocornine.

TABLE 1

EFFECT OF TIME OF ERGOCORNINE ADMINISTRATION TO PSEUDOPREGNANT RATS ON INCIDENGE OF SEGONDARY PSEUDOPREGNANCY

\begin{tabular}{c|c|c|c}
\hline \multirow{2}{*}{$\begin{array}{c}\text { No. } \\
\text { of } \\
\text { rats }\end{array}$} & $\begin{array}{c}\text { Day of } \\
\text { ergocornine } \\
\text { administration }\end{array}$ & \multicolumn{2}{|c}{ Secondary pseudopregnancies } \\
\cline { 3 - 4 } & Incidence & (days; mean \pm S.E. and range $)$ \\
\hline 20 & $\mathrm{~L}_{2}$ & $18 / 20$ & $12.0 \pm 0.4(9$ to 14$)$ \\
20 & $\mathrm{~L}_{4}$ & $11 / 20$ & $11.3 \pm 0.4(11$ to 15$)$ \\
20 & $\mathrm{~L}_{7}$ & $4 / 20$ & $10.3 \pm 1.0(8$ to 13$)$ \\
\hline
\end{tabular}

The difference between the groups treated on $L_{2}$ and on $L_{7}$ in the incidence of secondary pseudopregnancy is highly significant $\left(\chi^{2}=16.8 ; P<0.01\right)$.

The data in Table 1 suggest that the later oestrus is induced during the luteal phase, the shorter is the secondary pseudopregnancy, 8 to 13 days when ergocornine was given on $\mathrm{L}_{7}$. Normal for electrically-induced pseudopregnancy in 100 rats of our colony is $13.5 \pm 0.3$ days of leucocytic vaginal smear (range 11 to 18). Thus as pseudopregnancy progresses, the expression of 'memory' of the inducing stimulus appears to decrease.

This investigation was supported by grants from the Ford Foundation, Population Council and the SABA Foundation. The author is grateful to Professor M. G. Shelesnyak and Professor H. R. Lindner for the interest taken in this study and for editorial advice.

\section{REFERENCES}

Everetr, J. W. (1967) Provoked ovulation or long-delayed pseudopregnancy from coital stimuli in barbiturate-blocked rats. Endocrinology, 80, 145.

Kraicer, P. F. \& Shelesnyak, M. C. (1964) Studies on the mechanism of nidation. IX. Analysis of the responses to ergocornine-an inhibitor of nidation. F. Reprod. Fert. 8, 225.

Shelesnyak, M. C. (1955) Disturbance of hormone balance in the female rat by a single injection of ergotoxine ethanesulphonate. Am. F. Physiol. 180, 47.

Zencmaker, G. H. (1965) Normal and delayed pseudopregnancy in the rat. Acta endocr., Copenh. 41, 321. 